able to recuperate in Egypt during the winter of r9ooxgor. He joined Mr. Beadnell, of the Geological Survey of Egypt, in the Fayum, where there are freshwater deposits of early Tertiary age, and his keen eyes soon detected numerous remains of mammals which had not previously been noticed. Among these he recognised two successive ancestral elephants more primitive than Dinotherium and Mastodon, which he described under the now familiar names of Moeritherium and Palæomastodon. He thus showed that the African region was probably the original home of the Proboscidea, and in a paper published in the Philosophical Transactions of the Royal Society in 1904 , he described various specimens illustrating the early stages in the evolution of these strange mammals. In I902 Mr. Beadnell discovered the large horned mammal Arsinoitherium in the same district, and between 1902 and Igo6 Dr. Andrews again paid visits to the Fayum, thanks to the generosity of the late Mr.W. E. de Winton, and obtained valuable specimens of the most important extinct mammalian fauna which has been discovered during the present century. The whole collection made both by himself for the British Museum and by $\mathrm{Mr}$. Beadnell for the Geological Survey of Egypt, was eventually discussed by Dr. Andrews in " A Descriptive Catalogue of the Tertiary Vertebrata of the Fayum, Egypt," published by the Trustees of the British Museum in 1906. This deals especially with the beginnings of the Proboscidea, Hyracoidea, Sirenia, and Cetacea, and will always remain one of the classics of vertebrate palæontology.

Between I9II and I9I4 Dr. Andrews described and interpreted other important early Tertiary fossil mammals collected by Mr. C. W. Hobley and Dr. Felix Oswald in British East Africa, extending especially his observations on the Hyracoidea. At the time of his death he was looking forward to receiving another collection made last April by Mr. E. J. Wayland in a locality in Uganda whence a toe-bone of Chalicotherium was obtained a few months ago.

In the intervals of these more important researches, Dr. Andrews found time to deal with many smaller discoveries which were brought to his notice at the Museum. He was ever helpful and encouraging to visitors who submitted fossils for his consideration. His genial kindliness, which endeared him to both colleagues and friends, stood him in good stead as a curator, and he attracted many valuable gifts to the collection of the Museum. His keen insight into the meaning of the facts he observed illumined all his writings and made them fundamental contributions to science. The indomitable energy and enthusiasm with which he pursued his researches between the frequently recurring periods of illness during his later years, were altogether admirable. His scientific worth was recognised by his election to the fellowship of the Royal Society in 1906, and by the award of the Lyell Medal of the Geological Society of London in r9I6. His personal worth was appreciated by a large circle of devoted friends, both in Great Britain and abroad, who sincerely mourn his premature end.

A. S. W.

The many friends of Dr. Andrews will appreciate the following tribute from his surgeon :

" Like all surgeons I have had the privilege of meeting men who have faced the ordeal of a painful operation with courage. Andrews, however, will always remain in my mind as one of the bravest men I ever met. It is possible to hide the whole truth from some patients, so that their ignorance saves them distress. In the case of a scientific man this is impossible, and Andrews knew for many years that a time must come when nothing more could be done for him. None the less while he could work, he worked, and quite shortly before his death he was correcting the proof-sheets of a palæontological paper. He never complained, he never lost his courage, even when he was faced with not one but many operations. What this means only those who heve to do with surgery can really understand. His personal charm and thoughtfulness for others were known to all his friends, but to no one were they more evident than to those whose lot it was to be with him in his time of pain.

His scientific work is well known and will ever remain his monument, but I would like to add to his epitaph not only that he was a very kindly and lovable man but that he was a very brave one." A. E.

\section{Prof. E. F. Nichols}

According to a note by Prof. A. Trowbridge of Princeton University in the issue of Science for May 9, Prof. Ernest Fox Nichols, formerly professor of physics in Yale University, died suddenly on April 29 while addressing a meeting in the hall of the National Academy of Sciences at Washington.

Prof. Nichols was born in Kansas in 1870 , and, after studying at Cornell University and spending two years on research at Berlin, he received the doctorate of science in 1897 . He was professor of physics at Colgate and Dartmouth Colleges and Columbia University in succession, but in 1909 abandoned for a time scientific for administrative work and became president of Dartmouth. In r9r6 he took up the professorship of physics at Yale, but on the entry of the United States into the War, he joined the Naval Ordnance Department. In r920 he became director of the pure science research laboratory of the National Electric Lamp Works. For a short time in $\mathrm{x} 92 \mathrm{I}$ he was president of the Massachusetts Institute of Technology, but the state of his health led him to resign after a few months. He took a prominent part in the establishment in 1916 of the National Research Council and in its subsequent organisation.

Prof. Nichols's first paper was published in r893 while he was still at Cornell, and its title, "Studies of Transmission Spectra of Substances in the Infra Red," suggests the field in which a large proportion of his research work was done. Three years later he was cooperating with Rubens in Berlin in the production and measurement of infra-red radiation, and his last paper, published in 1923 , dealt with the same subject. In conjunction with Hull he succeeded in rgoI in measuring the pressure exerted by radiation on a body on which it falls, although the total force involved was only of the order of $10^{-5}$ dyne.

$\mathrm{WE}$ regret to announce the following deaths:

Prof. H. O. Hofman, emeritus professor of mining and metallurgy at the Massachusetts Institute of Technology, and an original member of the Institute of Metals, on April 28, aged seventy-one.

Mr. F. Merrifield, formerly president of the Entomological Society, on May 28, aged ninety-three.

$$
\text { NO. } 2849 \text {, VOL. I I } 3 \text { ] }
$$

